\title{
THERMAL STABILITY STUDY OF DIAMOND-LIKE CARBON FILMS CONTAINING CRYSTALLINE DIAMOND NANOPARTICLES
}

\section{ESTUDO DA ESTABILIDADE TÉRMICA DE FILMES DE CARBONO-TIPO DIAMANTE CONTENDO NANOPARTÍCULAS DE DIAMANTE INCORPORADAS}

\author{
Marina Fernandes Stein ${ }^{1}$ \\ Beatriz Campos Ramos ${ }^{2}$ \\ Fernanda Roberta Marciano ${ }^{3}$ \\ Anderson Oliveira Lobo ${ }^{3}$ \\ Vladimir Jesus Trava-Airoldi ${ }^{4}$
}

\begin{abstract}
Nanocrystalline diamond (NCD) particles are incorporated into diamond-like carbon (DLC) films in order to prevent NCD-DLC electrochemical corrosion. In the current paper, the thermal stability of these films was investigated. The NCD-DLC films were deposited on $316 \mathrm{~L}$ stainless steel substrates using plasma enhanced chemical vapor deposition. The grain size of the diamond crystallites and their concentration were varied in order to obtain different NCD-DLC films. The samples were annealed to $50^{\circ} \mathrm{C}$ for $1 \mathrm{~h}$. The annealing temperature increased until the complete graphitization of the films (ramp of $50^{\circ} \mathrm{C}$ ). Raman scattering spectroscopy was used to evaluate in detail the chemical structure of the DLC and NCD-DLC films. The atomic arrangements and graphitization level according to the increasing temperature are discussed. The influence of NCD particle sizes and concentration on NCD-DLC thermal stability are also discussed. The results showed that the presence of crystalline diamond particles increased the graphitization temperature, which permits the use of NCD-DLC films in high temperature environments.
\end{abstract}

Keywords: diamond-like carbon; nanocrystalline diamond particles; Raman spectroscopy.

Resumo: O estudo de filmes de carbono-tipo diamante (DLC) é atualmente de grande interesse da comunidade científica e tecnológica devido às suas propriedades físico-químicas, que podem ser significativamente aumentadas pela presença de nanopartículas em sua estrutura. O objetivo deste trabalho é a avaliação da estabilidade térmica de filmes de DLC contendo nanopartículas de diamante cristalino (NDC) em diferentes concentrações e granulometrias. Os filmes foram depositados pela técnica de deposição química da fase vapor assistida por plasma (PECVD), e caracterizados utilizando as técnicas de microscopia eletrônica de varredura (MEV) e de espectroscopia de espalhamento Raman. Os resultados indicam que a presença de NDC aumenta a temperatura de grafitização, permitindo a utilização dos filmes de NDC-DLC em ambientes de elevada temperatura.

Palavras-chave: carbono-tipo diamante; partículas de diamante nanocristalino; espectroscopia Raman.

\footnotetext{
1 Graduada em Química - Universidade do Vale do Paraíba - Univap. E-mail: steinmarina@ig.com.br.

${ }^{2}$ Mestranda em Engenharia Biomédica - Univap. E-mail: bia_campos2007@yahoo.com.br.

${ }^{3}$ Docente da Univap. E-mails: frmarciano@univap.br; aolobo@univap.br.

${ }^{4}$ Pesquisador do Instituto Nacional de Pesquisas Espaciais - INPE. E-mail: vladimir@las.inpe.br.
} 


\section{INTRODUCTION}

Diamond-like carbon (DLC) coatings have been actively studied over the last decade in the field of material engineering. Consisting of dense amorphous carbon or hydrocarbon, DLC mechanical properties fall between those of graphite and diamond (ROBERTSON, 2002; DONNET et al., 1999; DONNET; GRILL, 1997; YUN et al., 2008). It has been widely study due to its mechanical properties such as low friction coefficient, high hardness, and high adherence on different substrate materials (ROBERTSON, 2002; DONNET et al., 1999). However, the thermal degradation of DLC films is a major problem in achieving high temperature applications due to the conversions of $s p^{3}$ to $s p^{2}$ hybrid orbitals which forms the $\mathrm{C}-\mathrm{C}$ bonds and the loss of diamond-like properties ( $\mathrm{CHOl}$ et al., 2007). The investigation of thermal stability of DLC films deposited using plasma enhanced chemical vapor deposition (PECVD) technique showed changes in mechanical and tribological properties at temperatures greater than $200{ }^{\circ} \mathrm{C}$, resulting from $s p^{3}$ to $s p^{2}$ transformation accompanied with hydrogen effusion (LI et al., 2006).

Recent studies have reported modified-DLC films improved biocompatibility, lubricity, stability and cell adhesion (SHIRAKURA et al., 2006; HAUERT, 2003). Nanoparticle-dispersed composite films are expected to have the potential of changing their performances according to the individual properties of nanoparticles (BAN; HASEGAWA, 2012). According to Yun et al. (2008), these characteristics are related to structural bonds (ZHAO et al., 2007), surface roughness (MA et al., 2007) and whether the film is hydrophobic or hydrophilic (YOKOTA et al., 2007).

In our previous manuscript (MARCIANO et al., 2010a), it was show for the first time the use of DLC films with nanocrystalline diamond (NCD) particles incorporated in their structure. NCD particles increased DLC electrochemical corrosion resistance, reducing its nanopores and consequently preventing aggressive ions from attacking the stainless steel surface (MARCIANO et al., 2010a; MARCIANO et al., 2010b). However, the thermal stability of DLC films containing NCD particles (NCD-DLC) need to be studied. In the current paper, Raman scattering spectroscopy was used to investigate the thermal stability of NCD-DLC films at different concentration.

\section{EXPERIMENTAL PROCEDURES}

The $316 \mathrm{~L}$ stainless steel substrates $\left(1 \times 1 \mathrm{~cm}^{2}\right)$ were mechanically polished to a mirror-like finish surface, cleaned ultrasonically in an acetone bath for $15 \mathrm{~min}$ and dried in nitrogen atmosphere. The clean samples were mounted on a water-cooled, $10-\mathrm{cm}$ diameter cathode powered by a pulsed directly current plasma enhanced chemical vapor deposition power supply, with variable pulse voltage from 0 to $-1000 \mathrm{~V}$, at a frequency of $20 \mathrm{kHz}$ and duty-cycle of $50 \%$.

Into the chamber (vacuum base pressure of $1.3 \mathrm{mPa}$ ) the substrates were additionally cleaned by argon discharge with $1 \mathrm{sccm}$ gas flow at $11.3 \mathrm{~Pa}$ working pressure and a discharge voltage of $700 \mathrm{~V}$ for $10 \mathrm{~min}$ prior to deposition. In order to enhance the DLC film adhesion to metallic surfaces, a thin amorphous silicon interlayer (thickness around $200 \mathrm{~nm}$ ) were deposited using silane as the precursor gas ( $1 \mathrm{sccm}$ gas flow at $11.3 \mathrm{~Pa}$ for $12 \mathrm{~min}$ and a discharge voltage of $-700 \mathrm{~V}$ ) (MARCIANO et al., 2009). The DLC films were deposited using hexane as the feed gas to a thickness of around 
$2.0 \mu \mathrm{m}$ (at 18.0 Pa for $60 \mathrm{~min}$ and a discharge voltage of $-700 \mathrm{~V}$ ).

In order to produce NCD-DLC films, NCD particles from 4 and $500 \mathrm{~nm}$ average size dispersed in hexane at different concentration $(0.1$ and $1.0 \mathrm{~g} / \mathrm{L})$ replaced the pure hexane during the DLC deposition.

The dispersion of NCD nanoparticles in DLC films were analyzed using field emission gun scanning electron microscopy (FEG-SEM), JEOL JSM-6330F, with $30.0 \mathrm{kV}$.

The atomic arrangement of the films was analyzed by using Raman scattering spectroscopy (Renishaw 2000 system) with an $\mathrm{Ar}^{+}$-ion laser $(\lambda=514 \mathrm{~nm}$ ) in backscattering geometry. The laser power on the sample was $\sim 0.6 \mathrm{~mW}$. The diameter of laser spot was $2.5 \mu \mathrm{m}$. The Raman shift was calibrated in relation to the diamond peak at $1332 \mathrm{~cm}^{-1}$. All measurements were carried out in air at room temperature. The slopes of the photoluminescence background in visible Raman spectra were used to estimate the hydrogen content in the films, following the methodology described by Casiraghi et al. (CASIRAGHI; FERRARI; ROBERTSON, 2005a; CASIRAGHI; FERRARI; ROBERTSON, 2005b).

In order to investigate the thermal stability of the deposited films, thermal annealing ranged from $100^{\circ} \mathrm{C}$ to $500^{\circ} \mathrm{C}$ in air environment for $1 \mathrm{~h}$, with a heating rate of $15^{\circ} \mathrm{C} / \mathrm{min}$.

\section{RESULTS AND DISCUSSION}

The surface morphology of NCD-DLC film (500 nm) shown in Figure 1 confirmed that NCD particles were really incorporated in DLC films. SEM image also shows some nanoparticles completely immersed and others partially immersed in DLC surface. Despite the nanoparticles had a tendency to form aggregates on the surface during the deposition process (SILEIKATE, 2006), it was possible to reach a satisfatory density of NCD particles with the adopted methodology.

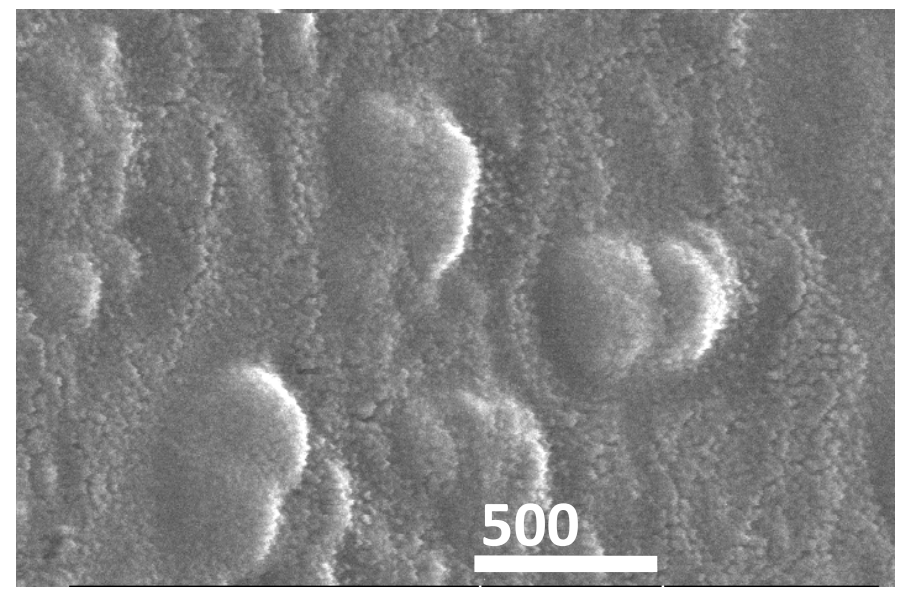

Figure 1 - SEM image of NCD-DLC film produced from NCD particles of $500 \mathrm{~nm}$ at $1.0 \mathrm{~g} / \mathrm{L}$. 
Raman scattering spectroscopy is popularly used to probe the quality of DLC films due to its ability to distinguish between different bonding types and domain sizes (FERRARI; ROBERTSON, 2000; TAMOR; VASSEL, 1994). Typical DLC spectra exhibit two distribution bands in the 1000-1800 $\mathrm{cm}^{-1}$ range, known as the $D\left(1350 \mathrm{~cm}^{-1}\right)$ and $G\left(1550 \mathrm{~cm}^{-1}\right)$ bands (CASIRAGHI; FERRARI; ROBERTSON, 2005a; CASIRAGHI; FERRARI; ROBERTSON, 2005b). These spectra were fitted using two Gaussian curves. The integrated intensity ratio of the $D$ and $G$ peaks $\left(I_{D} / I_{G}\right)$ has been correlated with the $s p^{3} / s p^{2}$ bonding ratio (CASIRAGHI; FERRARI; ROBERTSON, 2005a; CASIRAGHI; FERRARI; ROBERTSON, 2005b). In amorphous material, there is a complete loss of periodicity because the $G$ peak comprises all $\mathrm{sp}^{2}$ sites, but the $D$ peak only comprises six-fold rings. Therefore, $I_{D} / I_{G}$ falls as the number of rings per cluster and the fraction of chain groups rise (FERRARI; ROBERTSON, 2000; TAMOR; VASSEL, 1994).

To study the processes going on in different concentration of NCD particles of different sizes during the annealing procedure in more detail, Raman spectra have been recorded at different annealing temperatures.

Figure 2 shows the Raman spectra acquired from the as-deposited DLC films before and after the annealing $\left(400^{\circ} \mathrm{C}\right)$. Obvious difference among the Raman spectra of the films can be observed. The $G$ peak and $D$ peak positions shift upwards and the $D$ peak intensity increases, which indicates a severe degradation of the structural property of the films, i.e. the decreases of the $s p^{3}$ content and the diamond-like characterization and the increase of graphite-like component. The changes in these spectra might correlate with graphitization of amorphous carbon (FERRARI; ROBERTSON, 2000).

All the spectra were deconvoluted into $D$ and $G$ bands using two Gaussian curves.

The main factor affecting bands position, width and intensity is the clustering of $s p^{2}$ phase (CASIRAGHI; FERRARI; ROBERTSON, 2005a). The $G$ band position measures topological disorder, which arises from the size and shape distribution of $s p^{2}$ clusters (CASIRAGHI; FERRARI; ROBERTSON, 2005a). Figure 3 shows the $G$ band position of the films according to the annealing temperature. The experimental data mentioned above show that the effect of annealing on the DLC and NCD-DLC films can be divided into two stages. At low annealing temperature up to $200{ }^{\circ} \mathrm{C}$, there is only a very slight increase in $G$ band position. After this, the $G$ band position increases more accentuated until the complete delamination of the films. These results are in agreement with other groups (LI et al., 2006; ZIEBERT, 2005). Films with more quantity of NCD nanoparticles (independently of its gain size) takes longer to delaminate. Table 1 shows the temperature of delamination of the films according to the crystalline diamond grain size and concentration. This increase in delamination temperature due to the presence of more nanoparticles (increased NCD concentration) permits the use of NCD-DLC films in environments of high temperature. 

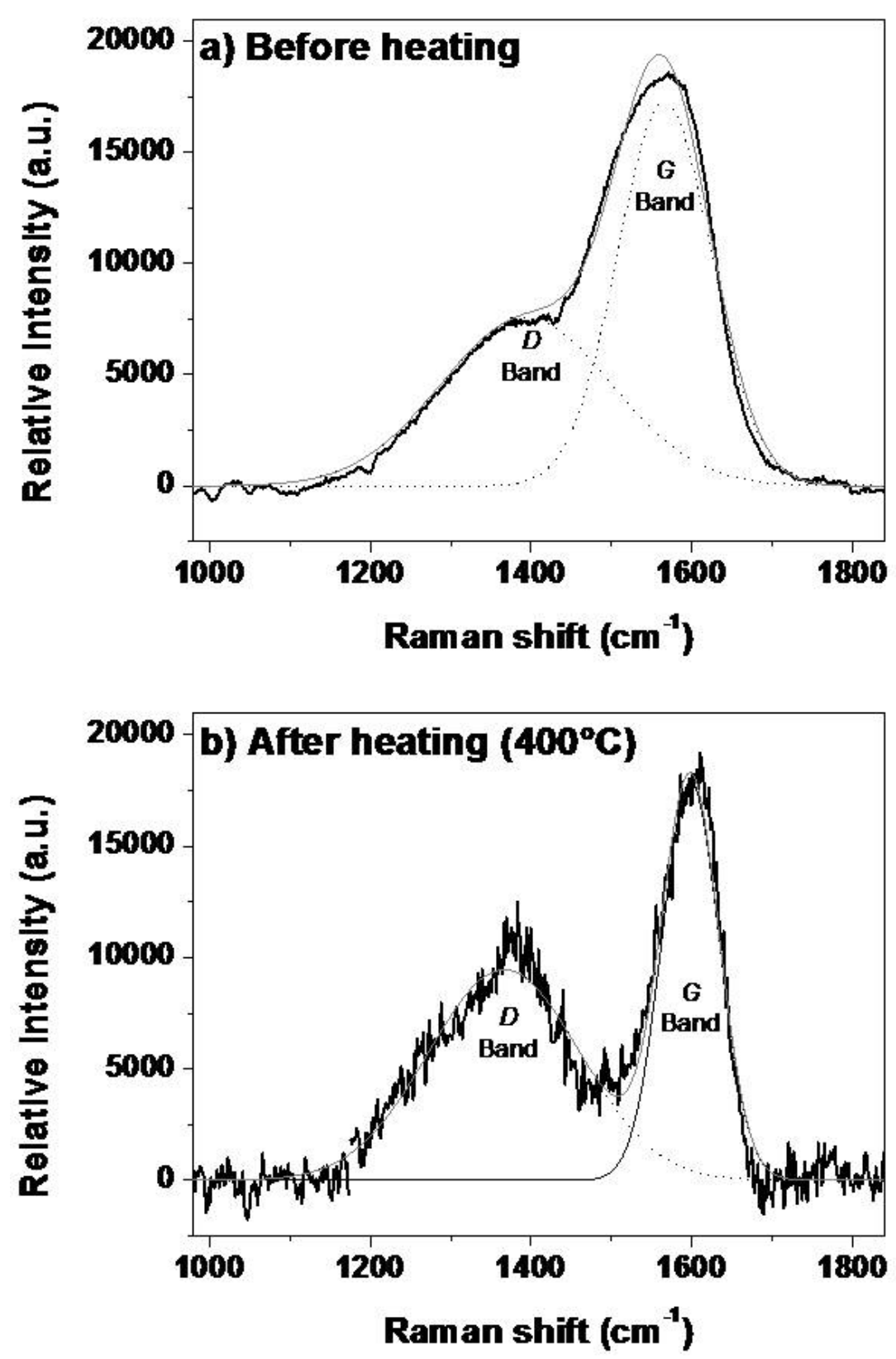

Figure 2 - Raman spectrum of DLC film (a) before and (b) after heating $\left(400^{\circ} \mathrm{C}\right)$. The spectra present two overlapping bands known as the $D$ and $G$ bands.

Table 1 - Temperatures of graphitization of the DLC film and the NCD-DLC particle-size of 4 to $500 \mathrm{~nm}$ at concentrations of 0.1 and $1.0 \mathrm{~g} / \mathrm{L}$

\begin{tabular}{|c|c|c|c|}
\cline { 2 - 4 } \multicolumn{1}{c|}{} & \multicolumn{3}{c|}{ Concentration $(\mathbf{g} / \mathbf{L})$} \\
\hline Particle-size & $\mathbf{0}$ & $\mathbf{0 , 1}$ & $\mathbf{1 , 0}$ \\
\hline 0 & $300^{\circ} \mathrm{C}$ & & \\
\hline $4 \mathrm{~nm}$ & & $450^{\circ} \mathrm{C}$ & $500^{\circ} \mathrm{C}$ \\
\hline $500 \mathrm{~nm}$ & & $400^{\circ} \mathrm{C}$ & $500^{\circ} \mathrm{C}$ \\
\hline
\end{tabular}



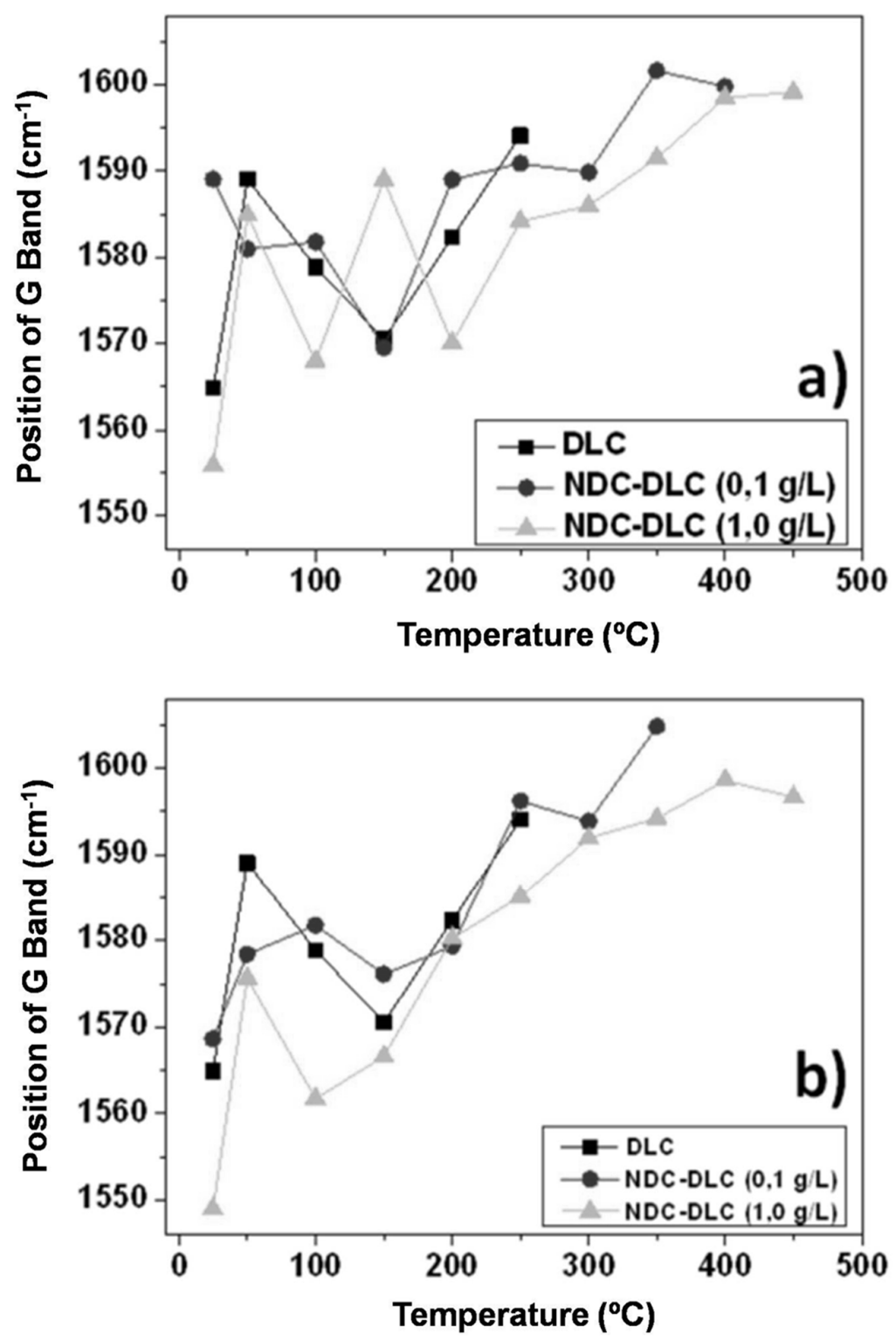

Figure 3 - Position of the G band of the DLC films and the NCD-DLC grain-size 4 (a) and 500 $\mathrm{nm}(\mathrm{b})$ at concentrations of 0.1 and $1.0 \mathrm{~g} / \mathrm{L}$.

\section{CONCLUSION}

This study shows for the the evolution of graphitization process of NDC-DLC thin films according to the increasing temperature. Raman spectroscopy revealed that the process of graphitization by annealing the samples shifts $G$ band position to longer wavelengths. Samples containing nanoparticles present a crystalline diamond graphitization process that is slower and occurs at higher temperatures. In films containing nanoparticles at higher concentrations, the temperature of graphitization increased by about $200^{\circ} \mathrm{C}$, which paves the way for new applications. 


\section{ACKNOWLEDGEMENTS}

This study was supported by Conselho Nacional de Desenvolvimento Científico e Tecnológico (CNPq) and Fundação de Amparo à Pesquisa do Estado de São Paulo (FAPESP 2011/17877-7 and 2011/20345-7).

\section{REFERENCES}

BAN, M.; HASEGAWA, N. Deposition of diamond-like carbon thin films containing photocatalytic titanium dioxide nanoparticles. Diamond and Related Materials, v. 25, p. 92-97, May 2012.

CASIRAGHI, C. et al. Bonding in hydrogenated diamond-like carbon by Raman spectroscopy. Diamond and Related Materials, v. 14, p. 1098-1102, Mar-Jul. 2005.

CASIRAGHI, C.; FERRARI, A. C.; ROBERTSON, J. Raman spectroscopy of hydrogenated amorphous carbons. Physical Review B, v. 72, p. 085401-085414, Aug. 2005.

$\mathrm{CHOI}, \mathrm{J}$. et al. The effects of Si incorporation on the thermal and tribological properties of DLC films deposited by PBII\&D with bipolar pulses. Surface and Coatings Technology, v. 201, p. 8357-8361, Aug. 2007.

DONNET, C. et al. Diamond-like carbon-based functionally gradient coatings for space tribology. Surface and Coatings Technology, v. 120-121, p. 548-554, Nov. 1999.

DONNET, C.; GRILL, A. Friction control of diamond-like carbon coatings. Surface and Coatings Technology, v. 94-95, p. 456-462, Oct. 1997.

FERRARI, A. C.; ROBERTSON, J. Interpretation of Raman spectra of disordered and amorphous carbon. Physical Review B, v. 61, p. 14095-14107, May 2000.

HAUERT, R. A review of modified DLC coatings for biological applications. Diamond and Related Materials, v. 12, p. 583-589, Mar-Jul. 2003.

$\mathrm{LI}, \mathrm{H}$. et al. Annealing effect on the structure, mechanical and tribological properties of hydrogenated diamond-like carbon films. Thin Solid Films, v. 515, p. 2153-2160, Dec. 2006.

MA, W. J. et al. DLC coatings: Effects of physical and chemical properties on biological response. Biomaterials, v. 28, p. 1620-1628, Mar. 2007.

MARCIANO, F. R. et al. Improvement of diamond-like carbon electrochemical corrosion resistance by addition of nanocrystalline diamond. Journal of Colloid and Interface Science, v. 342, p. 636-637, Feb. 2010.

MARCIANO, F. R. et al. Crystalline diamond particles into diamond-like carbon films: The influence of the particle sizes on the electrochemical corrosion resistance. Surface and Coatings Technology, v. 204, p. 2600-2604, May 2010.

MARCIANO, F. R. et al. Wettability and antibacterial activity of modified diamond-like carbon films. Applied Surface Science, v. 255, p. 8377-8382, Jul. 2009. 
ROBERTSON, J. Diamond-like amorphous carbon. Materials Science and Engineering. R., v. 37, n. 6, p. 129-281, May 2002.

SHIRAKURA, A. et al. Diamond-like carbon films for PET bottles and medical applications. Thin Solid Films, v. 494, p. 84-91, Jan. 2006.

SILEIKATE, A. et al. Analysis of silver nanoparticles produced by chemical reduction of silver salt solution. Materials Science (Medziagotyra), v. 12, p. 287-291, Oct. 2006.

TAMOR, M. A.; VASSEL, W. C. Raman fingerprinting of amorphous-carbon films. Journal of Applied Physics, v. 76, p. 3823-3830, Sept. 1994.

YOKOTA, T. et al. Cell adhesion to nitrogen-doped DLCs fabricated by plasma-based ion implantation and deposition method using toluene gas. Surface and Coatings Technology, v. 201, p. 8048-8051, Aug. 2007.

YUN, D. Y. et al. Effect of $\mathrm{H}_{2}$ and $\mathrm{O}_{2}$ plasma etching treatment on the surface of diamond-like carbon thin film. Applied Surface Science, v. 254, p. 7925-7928, Sep. 2008.

ZHAO, Q. et al. Bacterial adhesion on silicon-doped diamond-like carbon films. Diamond and Related Materials, v. 16, p. 1682-1687, Aug. 2007.

ZIEBERT, C. et al. Interfaces and temperature stability of stepwise graded DLC films studied by nanoindentation and Raman spectroscopy. Surface and Coatings Technology, v. 200, p. 1127-1131, Oct. 2005. 